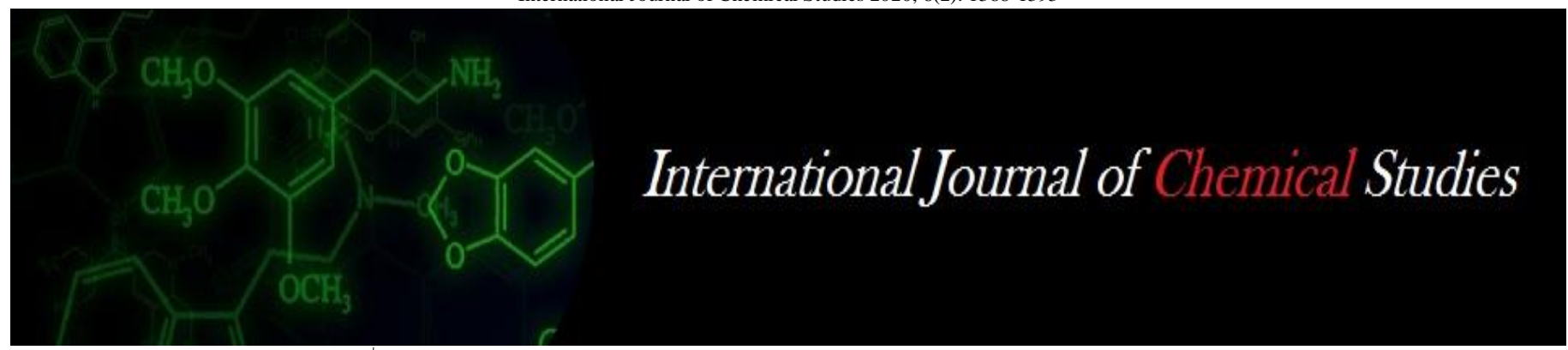

P-ISSN: 2349-8528

E-ISSN: 2321-4902

www.chemijournal.com

IJCS 2020; 8(2): 1388-1393

(C) 2020 IJCS

Received: 20-01-2020

Accepted: 24-02-2020

Pratap Singh Rathiya

IGKV, Potato and Temperate

Fruit Research Station, Mainpat,

Chhattisgarh, India

Rajendra Lakpale

IGKV, DKS College of

Agriculture and Research

Station, Bhatapara,

Chhattisgarh, India

Rupesh Deshmukh

Technical Assistant, Department

of Agronomy, IGKV, Raipur,

India
Corresponding Author: Pratap Singh Rathiya

IGK V, Potato and Temperate

Fruit Research Station, Mainpat,

Chhattisgarh, India

\section{Productivity and profitability of potato (Solanum tuberosum) genotypes as affected by varying levels of organic and inorganic sources of nutrients in northern hills of Chhattisgarh}

\author{
Pratap Singh Rathiya, Rajendra Lakpale and Rupesh Deshmukh
}

DOI: https://doi.org/10.22271/chemi.2020.v8.i2u.8957

\begin{abstract}
Field experiments were conducted during kharif of 2016 and 2017 at Mainpat, Chhattisgarh to investigate the effect of varying levels of organic and inorganic sources of nutrients on productivity and profitability of potato (Solanum tuberosum) genotypes. The treatments consisted three genotypes viz. Kufri Khyati, Kufri Pukhraj and Kufri Sinduri in main-plots and three nutrients sources viz. $100 \%$ RDF, $100 \%$ RDF + 5 t FYM ha ${ }^{-1}$ and $150 \%$ RDF in sub-plots. Potato genotypes had significantly variations in growth and yield attributes, total yield, nutrient uptake. Significantly higher growth attributes i.e plant height, number of shoot plant ${ }^{-1}$, dry weight of shoots and roots plant ${ }^{-1}$ and leaf area index (LAI) at 40 DAP and 60 DAP were recorded under Kufri Pukhraj. Hence, Kufri Pukhraj gave significantly higher fresh weight of tuber plant $^{-1}(317.79,320.79 \mathrm{~g})$, total tuber yield $\left(19.62,19.87 \mathrm{t} \mathrm{ha}^{-1}\right)$, NPK uptake, net return (₹187482, $\left.207300 \mathrm{ha}^{-1}\right)$ and B: C ratio $(3.15,3.28)$, except number of tubers plant ${ }^{-1}(15.40,15.81)$ were recorded in Kufri Sinduri. Among the varying nutrient sources $150 \%$ RDF of NPK showed better performance in all growth parameters, yield attributes and registered 17.19 to $17.80 \%$ more total yield of tuber when compared with others nutrient levels. The highest net return (₹168243, $\left.186329 \mathrm{ha}^{-1}\right)$ and B: C ratio $(2.89$, $3.01)$ was also recorded in $150 \%$ RDF treatments. The higher total tuber yield $\left(21.73 \mathrm{t} \mathrm{ha}^{-1}\right)$ were obtained from 'Kufri Pukhraj' genotype of potato treated with 150\% RDF.
\end{abstract}

Keywords: Productivity, profitability, nutrient uptake, integrated nutrient, potato genotypes

\section{Introduction}

Potato Known as "The King of vegetable" has emerged, as fourth most important food crop in Indian after rice, wheat and maize. Potato is major world food crop and plays important role in food security for ever increasing world population (Scott and Sourez, 2012) ${ }^{[21]}$. India is the second largest potato producer after China. In country, potato is grown about 2.17 million hectares with a total production of 49.34 million tonnes and productivity is 22.73 tonnes ha ${ }^{-1}$. (Anonymous, 2018) ${ }^{[2]}$. Potato grown under long days and rainfed conditions in high and mid hills in northwestern Himalayas, north eastern hills, southern hills and plateau region. In hilly areas it is grown in J\&K, Uttarakhand, H.P. North East and Southern hills and accounts $5 \%$ of total area under this crop (2.17 m ha). In plateau areas it is grown in M.P., Bihar, Chhattisgarh, Oddisa, Maharashtra and Karnataka and accounts about $8 \%$ of the total under the crop.

Potato is a unique crop and can be harvested early or late depending upon market price and requirement of field for subsequent crop. Besides, being highly exhaustive and responsive to nutrients, due to its high rate of production per unit area and time, it plays important role in solving hunger problem by increasing the productivity and efficiency of the resource in the production system. In Chhattisgarh, northern hills zone are more suitable for potato growing in kharif season and cultivated in an area of 1000 ha. The agricultural production system in the region is mostly rainfed, mono-cropped and at subsistence level. Productivity of the potato is much less than the national average. This situation may be improved by using improved potato genotypes having better yield potential and also adopting proper nutrient management practices. Hence, the present investigation was conducted to evaluate effect of different genotypes and varying levels of nutrients on productivity, profitability and nutrient uptake of kharif potato cultivation. 


\section{Materials and methods}

A field experiment was conducted during kharif (rainy) season of 2016 and 2017 at Instructional Farm, Potato and Temperate Fruit Research Station, Mainpat, Surguja, Chhattisgarh, located between $22^{0} 76^{\prime} \mathrm{N}$ latitude, $83^{0} 31^{\prime} \mathrm{E}$ longitude and $1075 \mathrm{~m}$ altitude, above mean sea level. The soil of the experimental site was sandy clay loam (Inceptisol) in texture with acidic in $\mathrm{pH}$ (6.13) and low organic carbon $(0.45 \%)$. The physico-chemical analysis of the soil was done by collecting soil samples from a depth of 0 to $15 \mathrm{~cm}$. The soil contained low nitrogen $\left(215.0 \mathrm{~kg} \mathrm{ha}^{-1}\right)$, medium in available phosphorus $\left(15.14 \mathrm{~kg} \mathrm{ha}^{-1}\right)$ and high potassium $\left(278.0 \mathrm{~kg} \mathrm{ha}^{-1}\right)$ respectively. The experiment was conducted in split plot design, replicated thrice, with three genotypes viz. Kufri Khyati, Kufri Pukhraj and Kufri Sinduri in the main plots and three varying fertility levels viz. 100\% RDF (180:100:100 kg ha-1 NPK), 100\% RDF + $5 \mathrm{t} \mathrm{FYM} \mathrm{ha}^{-1}$ and $150 \% \mathrm{RDF}$ in the sub-plots of $14.5 \times 4.5 \mathrm{~m}$ size. Basal dose of half of $\mathrm{N}$, full $\mathrm{P}$ and $\mathrm{K}$ were applied through urea, single super phosphate and muriate of potash respectively and rest of half of $\mathrm{N}$ was top dressed at 30 days after planting during each year experiment. Farmyard manure as per the treatments were applied as basal in both years. Sprouted tuber weighing 40 to $50 \mathrm{~g}$ each were placed in upright position in ridge $75 \mathrm{~cm}$ apart at a distance of $20 \mathrm{~cm}$. Planting was done on 16 July in 2016 and 10 July in 2017 in kharif season under rainfed conditions. Earthing up was done at 30 DAP in both years. To protect from early and late blight and other diseases, three spraying with Dithane M-45 (Mancozeb) @ $2.5 \mathrm{~kg} \mathrm{ha}^{-1}$ were done at 35, 50 and 65 DAP and for protecting against aphids, cut worm and other insects Chlorpyrifos 50\% + Cypermethrin 5\% EC @ $0.5 \mathrm{ml} \mathrm{liter}^{-1}$ of water was also sprayed at 45 and 65 DAP during both years. The rainfall received during the crop growth period was $1381 \mathrm{~mm}$ and $1022 \mathrm{~mm}$ in first and second year, respectively. Dehaulming was done in Kufri Khyati, Kufri Pukhraj and Kufri Sinduri at 75, 85 and 100 DAP when leaves start yellowing and falling, harvesting was done 10 to 12 days after dehaulming. Plant sample of tuber and haulm of potato collected at harvest of crop and oven dried at $50-60^{\circ} \mathrm{C}$ till constant weight and thus were grinded with the help of willey grinding mill and passed through $0.5 \mathrm{~mm}$ mesh sieve. Nitrogen, phosphorus and potassium content from tuber and haulm were estimated using standard procedures given by Jackson (1967) ${ }^{[7]}$. N, P and K uptake was worked out by using of nutrient content and biomass production data. The data on various variables were analysed by using statistical procedures as described by Gomez and Gomez (1984) ${ }^{[6]}$.

\section{Results and discussion Growth parameters}

The growth parameters of potato were significantly affected due to both variety and nutrient management practices applied during both years (Table 1). Among the potato varieties, viz. Kufri Pukhraj registered significantly higher plant height (78.22, 79.54), number of shoots plant ${ }^{-1}(7.59,7.96)$, dry weight of shoots plant ${ }^{-1}(26.35,27.06 \mathrm{~g})$, dry weight of roots plant $^{-1}(7.95,8.32 \mathrm{~g})$, LAI $(2.63,2.92)$ at 40 DAP and $(3.72$, $3.81)$ at 60 DAP as compared to other two varieties Kufri Khyati and Kufri Sinduri during both the years of experiment. Higher value of growth may attributed to its growth habits governed by genetic traits. Similar findings reported by Kumar et al. (2004) ${ }^{[14]}$ and Chaurasiya et al. (2016) ${ }^{[4]}$. The varietal differences in number of shoot plant $^{-1}$ might be due to genetic composition of variety (Baishya, et al. 2010) ${ }^{[3]}$. The lowest dry weight of shoots and root plant $^{-1}$, and LAI was found under the Kufri Khyati $\left(\mathrm{V}_{1}\right)$ but in plant height it was found at par with Kufri Sinduri $\left(\mathrm{V}_{3}\right)$, whereas number of shoots plant ${ }^{-1}$ was recorded minimum under Kufri Sinduri during both the years of investigation.

Among the nutrient management, significantly higher plant height $(78.09,79.18)$, number of shoots plant ${ }^{-1}(7.61,7.84)$, dry weight of shoots plant ${ }^{-1}(24.55,25.71 \mathrm{~g})$, dry weight of roots plant ${ }^{-1}(7.88,8.20 \mathrm{~g})$, LAI $(2.54,3.04)$ at 40 DAP and $(3.51,3.58)$ at 60 DAP of potato was noticed with the application of $150 \%$ RDF during both the years of experiment. It could be attributed to sufficient supply of nutrients during plant growth. Similar results were noticed by Upadhyaya et al. (2007). Adequate supply of NPK increased the protein formation, which leads to the maximum synthesis of plant tissues (Kumar et al. 2011) ${ }^{[12]}$. Adequate supply of NPK which is associated with higher photosynthetic activity leading to more number of shoots plant ${ }^{-1}$. The similar finding were reported by Adhikari and Karki (2006) ${ }^{[1]}$. Higher production of leaf area might be due to the fact that there was corresponding increase in vegetative growth with higher application of nutrients, thereby increasing the number of leaves. Moreover high value of LAI also might be due to adequate receipt of sunlight and higher leaf production. Similar finding also reported by Keisham et al. (2015) ${ }^{[9]}$. The high values of LAI throughout the growth period were also noticed by Kumar et al. (2005) ${ }^{[11]}$ due to high level of balanced fertilizer application. The minimum growth attributes was recorded under the application of $100 \% \mathrm{RDF}$ during both the years of investigations.

Table 1: Growth attributes of potato as influenced by genotypes and nutrient management

\begin{tabular}{|c|c|c|c|c|c|c|c|c|c|c|c|c|}
\hline \multirow{3}{*}{ Treatments } & \multirow{2}{*}{\multicolumn{2}{|c|}{$\begin{array}{l}\text { Plant height } \\
\text { (cm) }\end{array}$}} & \multirow{2}{*}{\multicolumn{2}{|c|}{$\begin{array}{l}\text { Shoots plant }{ }^{-1} \\
\text { (No.) }\end{array}$}} & \multirow{2}{*}{\multicolumn{2}{|c|}{$\begin{array}{c}\text { Dry weight of shoots plant } \\
\text { (g) }\end{array}$}} & \multirow{2}{*}{\multicolumn{2}{|c|}{$\begin{array}{c}\text { Dry weight of roots } \\
\text { plant }^{-1}(\mathrm{~g})\end{array}$}} & \multicolumn{4}{|c|}{ leaf area index (LAI) } \\
\hline & & & & & & & & & \multicolumn{2}{|c|}{40 DAP } & \multicolumn{2}{|c|}{ 60 DAP } \\
\hline & 2016 & 2017 & 2016 & 2017 & 2016 & 2017 & 2016 & 2017 & 2016 & 2017 & 2016 & 2017 \\
\hline \multicolumn{13}{|c|}{ Variety } \\
\hline $\mathrm{V}_{1}$-Kufri Khyati & 65.24 & 66.06 & 6.85 & 6.98 & 19.36 & 20.65 & 5.16 & 5.93 & 1.72 & 2.01 & 2.39 & 2.44 \\
\hline $\mathrm{V}_{2}$-Kufri Pukhraj & 78.22 & 79.54 & 7.59 & 7.96 & 26.35 & 27.06 & 7.95 & 8.32 & 2.63 & 2.92 & 3.72 & 3.81 \\
\hline $\mathrm{V}_{3}$-Kufri Sinduri & 68.15 & 69.08 & 6.21 & 6.58 & 22.97 & 23.82 & 6.69 & 7.59 & 2.28 & 2.47 & 3.54 & 3.59 \\
\hline SEm \pm & 1.76 & 1.82 & 0.07 & 0.10 & 0.19 & 0.24 & 0.32 & 0.15 & 0.09 & 0.07 & 0.04 & 0.05 \\
\hline $\mathrm{CD}(\mathbf{P}=0.05)$ & 6.93 & 7.14 & 0.27 & 0.39 & 0.75 & 0.92 & 1.25 & 0.57 & 0.34 & 0.29 & $\mathbf{0 . 1 7}$ & 0.21 \\
\hline \multicolumn{13}{|c|}{ Nutrient management } \\
\hline $\mathrm{F}_{1}-100 \% \mathrm{RDF}$ & 61.66 & 62.92 & 6.22 & 6.43 & 21.60 & 22.22 & 5.43 & 6.40 & 1.86 & 2.03 & 2.90 & 2.92 \\
\hline $\begin{array}{c}\mathrm{F}_{2}-100 \% \text { RDF + } 5 \text { t FYM } \\
\mathrm{ha}^{-1}\end{array}$ & 71.87 & 72.59 & 6.83 & 7.24 & 22.53 & 23.61 & 6.49 & 7.24 & 2.23 & 2.33 & 3.24 & 3.34 \\
\hline $\mathrm{F}_{3}-150 \% \mathrm{RDF}$ & 78.09 & 79.18 & 7.61 & 7.84 & 24.55 & 25.71 & 7.88 & 8.20 & 2.54 & 3.04 & 3.51 & 3.58 \\
\hline SEm \pm & 1.46 & 1.34 & 0.11 & 0.15 & 0.31 & 0.38 & 0.30 & 0.18 & $\mathbf{0 . 0 7}$ & 0.09 & 0.07 & 0.08 \\
\hline $\mathrm{CD}(\mathrm{P}=\mathbf{0 . 0 5})$ & 4.49 & 4.12 & 0.35 & 0.46 & 0.94 & 1.17 & 0.91 & 0.56 & 0.22 & 0.28 & 0.22 & 0.23 \\
\hline
\end{tabular}




\section{Yield attributing characters and yield}

Yield attributing characters and yield of potato was significantly influenced by varieties and nutrient management practices (Table 2). With respect to varieties, significantly the highest number of tubers plant ${ }^{-1}(15.40,15.81)$ was recorded under Kufri Sinduri as compared to Kufri Pukhraj and Kufri Khyati. The maximum fresh weight of tubers plant ${ }^{-1}$ (317.79, $320.79 \mathrm{~g})$, marketable yield $\left(17.79,17.95 \mathrm{t} \mathrm{ha}^{-1}\right)$ and total yield (19.62, $\left.19.87 \mathrm{t} \mathrm{ha}^{-1}\right)$ were noticed in Kufri Pukhraj and it was significantly superior to Kufri Khyati and Kufri Sinduri. The higher tuberization efficiency was observed under Kufri Khyati $(2.05,2.07)$ over other varieties during both years of investigation. This might be due to its growth habits governed by genetic traits and increased absorption of nutrients which increased photosynthetic activity as well as translocation of photosynthates for tubers formation. These results confirm with the findings by Kumar et al. (2004) ${ }^{[14]}$. Chaurasiya et al. (2016) ${ }^{[4]}$ also recorded higher number of tubers plant ${ }^{-1}$ in the variety of Kufri Sinduri and maximum fresh weight of tubers plant $^{-1}$ was found in Kufri Pukhraj followed by Kufri Khyati. Tuberization efficiency (tuber: haulm) was maximum values in short duration potato Kufri Khyati. This can be attributed to the genotypic differences between the cultivars (Joseph et al., 2011) ${ }^{[8]}$. High tuber yield of Kufri Pukhraj was mainly due to high tuber bulking resulting in greater tuber weight in comparison to other varieties. Sahu et al. (2016) ${ }^{[18]}$ have also recorded that significantly maximum total potato yields in Kufri Pukhraj followed by Kufri Khyati and Kufri Sinduri, which may be due to higher fresh weight of tuber, large size tubers and marketable tuber yield. This might be due to the inherent capacity of the variety to contribute differently in tuber productivity (Singh, 2005) ${ }^{[22]}$. The lowest marketable and total tuber yield were obtained in Kufri Sinduri during both years of investigation.

Among the nutrient levels, the significantly maximum number of tubers plant ${ }^{-1}(15.31,16.06)$, fresh weight of tubers plant ${ }^{-1}$
(335.77, 339.13g), tuberization efficiency (1.87, 1.91), marketable yield $\left(16.72,16.80 \mathrm{t} \mathrm{ha}^{-1}\right)$ and total tuber yield $\left(18.39,18.61 \mathrm{t} \mathrm{ha}^{-1}\right)$ were recorded with application of $150 \%$ RDF than other treatments during both years of experiment. This might be due to sufficient supply of nutrients which promoted larger, thick, dark green and succulent leaves production, it might be due to meristematic activities in plant cell. This also improves the efficient utilization of sunlight and other growth factors, which ultimately resulted the maximum production of photosynthates and translocation from leaf to tubers (Baishya et al., 2010) ${ }^{[3]}$. Tuber yield increased with application of inorganic fertilizers may be attributed to more availability of nutrient due to higher nutrient content that are released almost immediately which ultimately enhanced vegetative crop growth, higher synthesis of carbohydrates and translocation (Sarkar et al. 2011a) ${ }^{[19]}$. The minimum marketable and total tuber yield was obtained in $100 \%$ RDF during both years of investigation.

The interaction between different variety and nutrient levels was significantly affected and Kufri Pukhraj yielded significantly more with $150 \%$ RDF than other varieties and level of fertilizers during both the year of year (Table 3). The lowest tuber yield was noted in Kufri Sinduri when grown with $100 \%$ RDF. When $150 \%$ RDF was applied, yield of Kufri Sinduri increased by $24.65 \%$ whereas, yield increase of Kufri Pukhraj and Kufri Khyati was $19.99 \%$ and $8.81 \%$, respectively than other combinations on mean data. Higher total tuber yield in Kufri Pukhraj with $150 \%$ RDF can be attributed to the resultant higher vigour (plant height, number of shoot, number and size of tubers and haulms weight) with corresponding dose of fertilizers and also Kufri Pukhraj showed capacity to bulking (rate to increase tuber weight) faster and to reach its potential in shorter period. Similar varietal response to nutrient management has also been found by Baishya et al. (2010) ${ }^{[3]}$ and Kumar et al. (2009) ${ }^{[13]}$.

Table 2: Yield attributing characters and yield of potato as influenced by genotypes and nutrient management

\begin{tabular}{|c|c|c|c|c|c|c|c|c|c|c|}
\hline \multirow{2}{*}{ Treatments } & \multicolumn{10}{|c|}{ 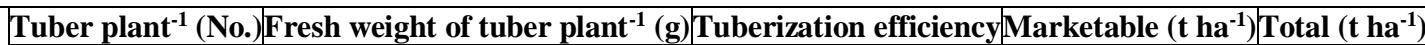 } \\
\hline & 2016 & 2017 & 2016 & 2017 & 2016 & 2017 & 2016 & 2017 & 2016 & 2017 \\
\hline \multicolumn{11}{|c|}{ Variety } \\
\hline V1-Kufri Khyati & 11.50 & 12.04 & 289.88 & 291.86 & 2.05 & 2.07 & 15.09 & 15.30 & 16.70 & 17.04 \\
\hline $\mathrm{V}_{2}$-Kufri Pukhraj & 12.85 & 14.25 & 317.79 & 320.79 & 1.75 & 1.83 & 17.79 & 17.95 & 19.62 & 19.87 \\
\hline $\mathrm{V}_{3}$-Kufri Sinduri & 15.40 & 15.81 & 266.73 & 272.06 & 1.48 & 1.53 & 13.19 & 13.32 & 14.39 & 14.63 \\
\hline SEm \pm & 0.26 & 0.31 & 3.02 & 1.99 & $\mathbf{0 . 0 3}$ & 0.04 & 0.37 & 0.31 & 0.37 & 0.32 \\
\hline $\mathrm{CD}(\mathrm{P}=\mathbf{0 . 0 5})$ & 1.01 & 1.23 & 11.87 & 7.80 & 0.10 & 0.14 & 1.45 & 1.20 & 1.44 & 1.27 \\
\hline \multicolumn{11}{|c|}{ Nutrient management } \\
\hline $\mathrm{F}_{1}-100 \% \mathrm{RDF}$ & 11.39 & 12.13 & 245.26 & 250.85 & 1.66 & 1.71 & 14.18 & 14.36 & 15.61 & 15.88 \\
\hline $\mathrm{F}_{2}-100 \% \mathrm{RDF}+5 \mathrm{t} \mathrm{FYM} \mathrm{ha}{ }^{-1}$ & 13.05 & 13.90 & 293.38 & 294.73 & 1.75 & 1.80 & 15.17 & 15.40 & 16.72 & 17.05 \\
\hline $\mathrm{F}_{3}-150 \% \mathrm{RDF}$ & 15.31 & 16.06 & 335.77 & 339.13 & 1.87 & 1.91 & 16.72 & 16.80 & 18.39 & 18.61 \\
\hline SEm \pm & $\mathbf{0 . 3 8}$ & 0.24 & 2.41 & 3.71 & $\mathbf{0 . 0 3}$ & $\mathbf{0 . 0 3}$ & 0.15 & 0.18 & 0.16 & 0.19 \\
\hline $\mathrm{CD}(\mathrm{P}=0.05)$ & 1.17 & 0.74 & 7.42 & 11.42 & 0.08 & 0.08 & 0.48 & 0.54 & 0.49 & 0.60 \\
\hline
\end{tabular}

Table 3: Interaction effect of total tuber yield of potato $\left(\mathrm{t} \mathrm{ha}^{-1}\right)$ as influenced by genotypes $\mathrm{x}$ nutrient management

\begin{tabular}{|c|c|c|c|c|}
\hline \multirow{2}{*}{$\begin{array}{c}\text { Nutrient } \\
\text { management }\end{array}$} & \multicolumn{3}{|c|}{ Variety } & \multirow[b]{2}{*}{ Mean } \\
\hline & V $_{1}$-Kufri Khyati & V2-Kufri Pukhraj & $\mathbf{V}_{3}$-Kufri Sinduri & \\
\hline $\mathrm{F}_{1}-100 \% \mathrm{RDF}$ & 16.11 & 18.11 & 13.02 & 15.75 \\
\hline $\mathrm{F}_{2}-100 \% \mathrm{RDF}+5 \mathrm{t} F Y M \mathrm{ha}^{-1}$ & 16.97 & 19.40 & 14.29 & 16.88 \\
\hline $\mathrm{F}_{3}-150 \% \mathrm{RDF}$ & 17.53 & 21.73 & 16.23 & 18.50 \\
\hline Mean & 16.87 & 19.75 & 14.51 & \\
\hline SEm \pm & 0.28 & & & \\
\hline $\mathrm{CD}(\mathrm{P}=0.05)$ & 0.87 & & & \\
\hline
\end{tabular}




\section{NPK uptake}

The higher total N P and K uptake (haulm + tubers) by potato was recorded in Kufri Pukhraj as compared to Kufri Khyati and Kufri Sinduri, but it was recorded at par with Kufri Sinduri in $\mathrm{N}$ uptake during both year of investigation. Significantly, higher uptake of N, P and K by Kufri Pukhraj in its haulm and tubers indicated its capacity to utilize soil and applied nutrients better as compared to Kufri Sinduri and Kufri Khyati. It also may be due to more dry matter accumulation, biological yield and higher NPK content in these treatments. Kumar et al. (2009) ${ }^{[13]}$ also indicated the better efficiency of variety Kufri Pukhraj in utilizing soil and applied NPK nutrient. This higher uptake was also mainly due to higher tubers and haulm production (Kumar and Trehan, 2012) ${ }^{[10]}$. The minimum total uptake N, P and K uptake by potato was noticed in Kufri Khyati, but it was statistically at par with Kufri Sindhuri in P and K uptake during both years of investigation

Among the nutrient levels the highest total N, P and K uptake (haulm + tubers) by potato was noticed with $150 \% \mathrm{RDF}$ through inorganic fertilizers which was significantly higher compared to other nutrient levels. It might be due to maximum nutrients are required for the well vegetative growth as well as stolons and tubers formation of potato the result conformity with Sarkar et al. (2011a) ${ }^{[19]}$ and Patel et al. (2015) [16]. Mondal et al. (2007) [15] also reported that sufficient supply of nutrients which improved in physical condition of the soil and thus the nutrients become readily availability to the crop. Significantly maximum $\mathrm{P}$ uptake with increasing level of NPK was possibly due to higher production of dry matter as well as higher $\mathrm{P}$ content. Higher $\mathrm{P}$ fertilization might have increased the cation exchange capacity of plant-roots and soil makes them efficient in absorbing P (Detroja et al., 1995) ${ }^{[5]}$. The minimum N, P and $\mathrm{K}$ uptake by potato (plant + tubers) were observed in $100 \%$ $\mathrm{RDF}$ applied to potato during both years of experiment.

\section{Economics}

The data on cost of cultivation, ( $\left.₹ \mathrm{ha}^{-1}\right)$, net returns $\left(₹ \mathrm{Fa}^{-1}\right)$ and $\mathrm{B}: \mathrm{C}$ ratio as affected by various treatments (Table 4 ). Results revealed that all the treatments had pronounced effects on the economics of potato during both years of experiment. Similar cost of cultivation ( $₹ 87198,90817 \mathrm{ha}^{-1}$ ) was recorded in all potato varieties, but the nutrient levels maximum cost of cultivation (₹89155, $92754 \mathrm{ha}^{-1}$ ) were recorded when crop received $150 \% \mathrm{RDF}$ and minimum was obtained in the $100 \%$ RDF treatment.

Among the varieties, Kufri Pukhraj brought out the maximum net return of (₹187482, $\left.207300 \mathrm{ha}^{-1}\right)$ with a B: C ratio (3.15, $3.28)$ respectively, which excelled over those computed under other varieties during both years of investigation. This might be due to higher production potential of potato variety accompanied with good monetary return. Trehan (2005) [23] also had similar observation regarding the efficiency of Kufri Pukhraj variety. The lowest net return and B: C ratio were obtained in Kufri Sinduri during both years of investigation.

The result revealed that net return and $\mathrm{B}: \mathrm{C}$ ratio increased with increasing levels of nutrients than the lower dose of nutrients during both the years. The maximum net returns ( $₹$ 168243, $186329 \mathrm{ha}^{-1}$ ) and B: C ratio (2.89, 3.01), were obtained from the potato crop fertilized with $150 \%$ RDF during both years of investigation. The minimum net profit and $\mathrm{B}$ : $\mathrm{C}$ was obtained in $100 \% \mathrm{RDF}$. This might be due to higher productivity without proportionate increase in cost of cultivation. Similar findings also noticed by Yadav et al., (2015) ${ }^{[25]}$. The increase in net returns from the use of inorganic sources of nutrients may be attributed to tuber number and yield as compared to organic manure (Kumar et al. 2005) ${ }^{[11]}$. Sarkar, et al. (2011b) ${ }^{[20]}$ also concluded that adequate supply of inorganic fertilizers in suitable proportion improved potato productivity.

Table 4: Total NPK uptake (tuber+ haulm) and economics by potato crop as influenced by genotypes and nutrient management

\begin{tabular}{|c|c|c|c|c|c|c|c|c|c|c|c|c|}
\hline \multirow[t]{2}{*}{ Treatments } & \multicolumn{2}{|c|}{$\begin{array}{l}\text { Nitrogen uptake } \\
\left(\mathrm{kg} \mathrm{ha}^{-1}\right)\end{array}$} & \multicolumn{2}{|c|}{$\begin{array}{c}\text { Phosphorus uptake } \\
\left(\mathrm{kg} \mathrm{ha}^{-1}\right)\end{array}$} & \multicolumn{2}{|c|}{$\begin{array}{c}\text { Potassium uptake } \\
\left(\mathrm{kg} \mathrm{ha}^{-1}\right)\end{array}$} & \multicolumn{2}{|c|}{$\begin{array}{c}\text { Cost of cultivation } \\
\left(₹ \mathrm{ha}^{-1}\right)\end{array}$} & \multicolumn{2}{|c|}{$\begin{array}{l}\text { Net return } \\
\left(₹ \text { ha }^{-1}\right)\end{array}$} & \multicolumn{2}{|c|}{ B:C ratio } \\
\hline & 2016 & 2017 & 2016 & 2017 & 2016 & 2017 & 2016 & 2017 & 2016 & 2017 & 2016 & 2017 \\
\hline \multicolumn{13}{|c|}{ Variety } \\
\hline $\mathrm{V}_{1}$-Kufri Khyati & 141.46 & 153.60 & 50.17 & 55.42 & 263.35 & 268.32 & 87198 & 90817 & 146633 & 164766 & 2.68 & 2.81 \\
\hline $\mathrm{V}_{2}$-Kufri Pukhrai & 184.57 & 194.44 & 66.34 & 75.32 & 315.01 & 318.95 & 87198 & 90817 & 187482 & 207300 & 3.15 & 3.28 \\
\hline $\mathrm{V}_{3}$-Kufri Sinduri & 175.26 & 181.65 & 54.18 & 62.01 & 259.43 & 261.98 & 87198 & 90817 & 114309 & 128583 & 2.31 & 2.41 \\
\hline SEm \pm & 6.26 & 4.09 & 2.37 & 1.78 & 8.71 & 4.81 & - & - & 5122 & 4870 & 0.06 & 0.05 \\
\hline $\mathrm{CD}(\mathrm{P}=0.05)$ & 24.58 & 16.04 & 9.32 & 6.99 & 34.20 & 18.89 & - & - & 20111 & 19123 & 0.23 & 0.21 \\
\hline \multicolumn{13}{|c|}{ Nutrient management } \\
\hline $\mathrm{F}_{1}-100 \% \mathrm{RDF}$ & 139.62 & 151.38 & 48.56 & 55.27 & 252.16 & 256.73 & 84554 & 88153 & 134048 & 150063 & 2.59 & 2.70 \\
\hline $\begin{array}{c}\mathrm{F}_{2}-100 \% \mathrm{RDF}+ \\
5 \mathrm{t} \mathrm{FYM} \mathrm{ha}^{-1}\end{array}$ & 168.06 & 178.42 & 56.04 & 61.67 & 276.04 & 279.77 & 87884 & 91543 & 146134 & 164257 & 2.66 & 2.79 \\
\hline $\mathrm{F}_{3}-150 \% \mathrm{RDF}$ & 193.62 & 199.89 & 66.09 & 75.82 & 309.59 & 312.74 & 89155 & 92754 & 168243 & 186329 & 2.89 & 3.01 \\
\hline SEm + & 6.39 & 4.69 & 1.54 & 1.74 & 6.53 & 6.29 & - & - & 2211 & 2902 & $\mathbf{0 . 0 3}$ & 0.03 \\
\hline $\mathrm{CD}(\mathrm{P}=\mathbf{0 . 0 5})$ & 19.68 & 14.45 & 4.76 & 5.37 & 20.13 & 19.37 & - & - & 6812 & 8943 & 0.08 & 0.10 \\
\hline
\end{tabular}

Market Price: 20162017

(₹ $\left.\mathrm{q}^{-1}\right) 14001500$

\section{Economic efficiency, production efficiency and} productivity rating index

The data pertaining to economic efficiency, production efficiency and production rating index as affected by varieties and nutrient management (Table 5). Among the varieties, significantly the maximum economic efficiency $(6.24,6.78)$ was noticed in Kufri Pukhraj, but production efficiency (208.78, $212.99 \mathrm{~kg} \mathrm{ha}^{-1}$ day $\left.^{-1}\right)$ and production rating index $(83.51,85.19 \%)$ were recorded in Kufri Khyati but it was found at par with Kufri Pukhraj in production efficiency during both year of experiments. Maximum economic efficiency was found in Kufri Pukhraj, it might due to higher production potential and more remunerative price of the potato. Whereas higher production efficiency and production rating index were recorded in Kufri Khyati, it might be due to increase in production and better land use efficiency by inclusion of early maturity ( 80 days) potato cultivars. Similar findings also noticed by Roy et al. (1999) ${ }^{[17]}$. The minimum 
economic efficiency, production efficiency and production rating index were recorded in Kufri Sinduri during both years of experiment.

Regarding the nutrient management, crop applied 150\% RDF was observed the maximum economic efficiency $(5.85,6.34)$, production efficiency $\left(197.22,199.70 \mathrm{~kg} \mathrm{ha}^{-1}\right.$ day $\left.^{-1}\right)$ and production rating index $(79.06,83.28 \%)$ during both year of investigations. This might be due higher productivity which gave higher economic return. The minimum economic efficiency, production efficiency and production rating index were observed in $100 \%$ during both year of investigations.

Table 5: Economic efficiency, production efficiency and productivity rating index in potato crop as influenced by potato genotypes and nutrient management

\begin{tabular}{|c|c|c|c|c|c|c|}
\hline \multirow{2}{*}{ Treatments } & \multicolumn{2}{|c|}{ Economic efficiency } & \multicolumn{2}{|c|}{ Production efficiency $\left(\mathrm{kg} \mathrm{ha}^{-1}\right.$ day $\left.^{-1}\right)$} & \multicolumn{2}{|c|}{ Productivity rating index $(\%)$} \\
\hline & 2016 & 2017 & 2016 & 2017 & 2016 & 2017 \\
\hline \multicolumn{7}{|c|}{ Variety } \\
\hline $\mathrm{V}_{1}$-Kufri Khyati & 5.31 & 5.81 & 208.78 & 212.99 & 83.51 & 85.19 \\
\hline $\mathrm{V}_{2-\text { Kufri Pukhraj }}$ & 6.24 & 6.78 & 206.53 & 209.20 & 72.79 & 79.50 \\
\hline $\mathrm{V}_{3}$-Kufri Sinduri & 4.58 & 4.99 & 130.85 & 132.97 & 65.42 & 66.48 \\
\hline SEm \pm & $\mathbf{0 . 1 2}$ & $\mathbf{0 . 1 1}$ & 3.65 & 3.54 & 0.81 & 1.30 \\
\hline $\mathrm{CD}(\mathrm{P}=\mathbf{0 . 0 5})$ & 0.46 & 0.43 & 14.33 & 13.91 & 3.18 & 5.09 \\
\hline \multicolumn{7}{|c|}{ Nutrient management } \\
\hline $\mathrm{F}_{1}-100 \% \mathrm{RDF}$ & 4.97 & 5.41 & 168.70 & 171.58 & 69.26 & 71.34 \\
\hline $\mathrm{F}_{2}-100 \%$ RDF + 5 t FYM ha ${ }^{-1}$ & 5.32 & 5.81 & 180.23 & 183.89 & 73.42 & 76.56 \\
\hline $\mathrm{F}_{3}-150 \%$ RDF & 5.85 & 6.34 & 197.22 & 199.70 & 79.06 & 83.28 \\
\hline SEm \pm & 0.05 & $\mathbf{0 . 0 7}$ & 1.71 & 1.94 & 0.90 & 0.88 \\
\hline $\mathrm{CD}(\mathrm{P}=0.05)$ & 0.15 & 0.20 & 5.27 & 5.96 & 2.77 & 2.71 \\
\hline
\end{tabular}

\section{References}

1. Adhikari BH, Karki KB. Effect of potassium on potato tuber production in acid soils of Malepatan Pokhara. Agric. Res. J. 2006; 7:42-48.

2. Anonymous. Horticulture Statistics Division. Dept. of Agri., Coop. \& Farmers Welfare, Government of India, New Delhi, 2018.

3. Baishya LK, Kumar M, Ghosh DC. Effect of different proportion of organic and inorganic nutrients on productivity and profitability of potato (Solanum tuberosum) varieties in Meghalaya hills. Indian Journal of Agronomy. 2010; 55(3):230-234.

4. Chaurasiya PC, Mishra RK, Mishra S. Varietal evaluation of potato under Northern hilly zone of Chhattisgarh. Int. J. of Tro. Agri. 2016; 34(50):12411246.

5. Detroja HJ, Sukhandia NM, Malviya DD. Yield and nutrient uptake by fenugreek (Trigonnella foenumgraecum L.) as influenced by nitrogen, phosphorus and potash. Indian Journal of Agronomy. 1995; 40(1):160161.

6. Gomez KA, Gomez AA. Statistical procedures for Agriculture Research. $2^{\text {nd }}$ edition. John Willey and Sons. New York, 1984.

7. Jackson ML. Soil Chemical Analysis. Prentice Hall Publication Pvt. Ltd., New Delhi, India, 1967; 452p.

8. Joseph TA, Singh BP, Kaushik SK, Bhardwaj V, Pandey SK, Singh PH et al. Kufri Girdhari: a medium maturing, late blight resistant potato variety for cultivation in Indian hills. Potato J. 2011; 38(1):26-31.

9. Keisham A, Heisnam P, Moirangthem A, Das T, Singh LN. Effect on growth and yield of potato (Solanum tuberosum) var. Kufri Jyoti by nitrogen with different organic sources and its after effect on soil. The Bioscan. 2015; 10(3):1335-1338.

10. Kumar M, Trehan SP. Influence of potato cultivars and N levels on contribution of organic amendments to $\mathrm{N}$ nutrition. Potato J. 2012; 39(2):133-144.

11. Kumar M, Gupta VK, Gogoi MB, Kumar S, Lal SS, Baishya LK. Effect of poultry manure on potato production under rainfed condition of Meghalaya. Potato J. $2005 ; 32(3-4): 242$
12. Kumar M, Baishya LK, Ghosh DC, Gupta VK. Yield and quality of potato (Solanum tuberosum) tubers as influenced by nutrients sources under rained conditions of Meghalaya. Indian Journal of Agronomy. 2011; 56(3):260-266.

13. Kumar M, Trehan SP, Jatav MK, Lal SS. Efficacy of potato (Solanum tuberosum) cultivars under varying levels of nitrogen and growth duration in eastern IndoGangetic plains. Indian Journal of Agronomy. 2009; 54(1):63-68.

14. Kumar R, Pandey SK, Uppal DS, Marwaha RS. Evaluation of potato (Solanum tuberosum) varieties for productionof chips. Indian Journal of Agricultural Sciences. 2004; 74(11):578-582.

15. Mondal SS. Saha M, Acharya D, Patra D, Chatterjeei S. Integrated effect of nitrogen and potassium with or without sulphur and farmyard manure on potato tuber yield, storage quality and soil fertility status. Potato J. 2007; 34(1-2):97-98.

16. Patel B, Sharma PK, Patanwa M, Chetna B, Patel P. Effect of different levels of nitrogen, phosphorus and potassium on nutrient uptake by potato, available nutrient in plant and soil fertility. Research Journal of Agricultural Sciences. 2015; 6(1):134-137.

17. Roy SC, Sharma RC, Sud KC. Production potential, profitability and soil fertility as affected by potato-based cropping sequence in N.W. plains of Punjab. J. Indian Potato Assoc. 1999; 26:33-38.

18. Sahu E, Sarnaik DA, Sharma PK, Barik SB, Yadav V. Influence of different levels of nitrogen on potato cultivars under Chhattisgarh plains in dorsa soil. Progressive Horticulture. 2016; 48(1):87-91.

19. Sarkar A, Sarkar S, Zaman A. Growth and yield of potato as influenced by combination of organic manures and inorganic fertilizers. Potato J. 2011a; 38(1):78-80.

20. Sarkar A, Sarkar S, Zaman A, Devi WP. Productivity and profitability of different cultivars of potato (Solanum tuberosum) as effected by organic and inorganic sources of nutrients. Indian Journal of Agronomy. 2011b; 56(2):159-163. 
21. Scott GJ, Sourez V. The rise of Asia as the center of global potato production and some implications for industry. Potato J. 2012; 39(3-4):1-22.

22. Singh BP. Potato cultivars for NEH region of India. Extension Bulletin No. 41, Central Potato Research Institute, Shimla, 2005.

23. Trehan SP. Nutrient management by exploiting genetic diversity of potato- a review. Potato J. 2005; 32(1-2):115.

24. Upadhyaya NC, Singh N, Ranwal S, Kumar P. Response of two cultivars to vermicompost and inorganic fertilizers. Journal of Indian Potato Association. 2003; 30(1-2):85-86.

25. Yadav SK, Srivastava AK, Bagh TK, Kumar S, Kumar S. Productivity, profitability and resources use efficiency of potato (Solanum tuberosum) based cropping system in eastern Himalayan region. Indian Journal of Agricultural Sciences. 2015; 85(7):921-925. 